
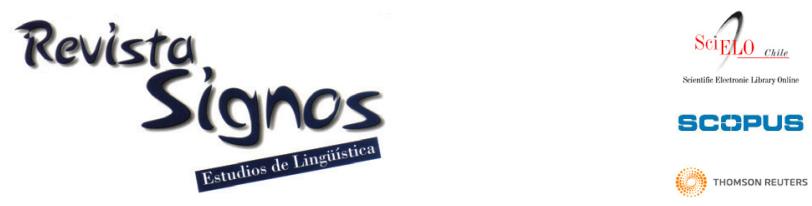

\title{
Attribution of responsibility by Spanish and English speakers: How native language affects our social judgments
}

Atribución de responsabilidad en español e inglés: Cómo afecta
nuestra lengua materna a nuestros juicios sociales

\author{
Richard Tillman \\ University of Tilburg \\ UNIVERSITY OF MEMPhis \\ USA \\ r.n.tillman@uvt.nl
}

William Langston

Middle Tennessee State University

USA

william.langston@mtsu.edu
Max Louwerse

University OF TiLbURG

UNIVERSITY OF MEMPHIS

USA

m.m.louwerse@uvt.nl

Recibido: 23-VI-2012 / Aceptado: 22-I-2013

\begin{abstract}
The relationship between language and thought has received a great deal of attention in linguistics. An increasing amount of empirical literature now suggests that our native language can affect how we think about the world around us. The present study asked two groups of participants to read the same story and to judge the attribution of the responsibility of a character in the story who may have caused an accident. One group of participants consisted of native Spanish speakers reading a Spanish version of the text; the other group consisted of native English speakers reading an English version of the text. The results showed that the native language of the participant yielded a subtle, but significant, indicator of attribution of responsibility. This finding supports the linguistic relativity hypothesis, which states that one's native language affects the way one conceptualizes the world.
\end{abstract}

Key Words: Linguistic relativity, Whorf, attribution of responsibility, agentive, crosscultural. 


\section{Resumen}

La relación entre lenguaje y pensamiento ha recibido gran atención en el campo de la lingüística. Cada vez más investigadores han demostrado de manera empírica que nuestra lengua materna puede afectar la forma en que conceptualizamos el mundo que nos rodea. El presente estudio pidió a dos grupos de participantes leer la misma historia y juzgar la atribución de la responsabilidad de un personaje de la historia que pudo haber causado un accidente. Un grupo de participantes eran hablantes nativos de español y leyeron la versión en español del texto y el otro grupo, hablantes nativos de inglés que leyeron la versión en inglés del texto. Los resultados mostraron que la lengua materna de los participantes era un indicador sutil, pero significativo de la atribución de la responsabilidad. Este hallazgo apoya la hipótesis de la relatividad lingüística que establece que la lengua materna afecta la forma en que uno conceptualiza el mundo.

Palabras Clave: Relatividad lingüística, Whorf, atribución de responsabilidad, agentivo, intercultural.

\section{INTRODUCTION}

When an official states 'a mistake was made', his or her responsibility for the error seems limited. However, when 'an official made a mistake', he or she will likely be held fully accountable for the error. Subtle differences in the linguistic structure of the sentence could have important ramifications on the psychological consequences of the sentence. Perhaps it is therefore no surprise that presidents commonly state that 'mistakes were made' rather than use the agentive wording that 'we made a mistake'. North American Presidents Reagan, Bush, Clinton, G. W. Bush, and Obama have used this non-agentive phrase in at least one of their speeches to perhaps shift responsibility away from themselves or their administrations (Peters, 2010).

The idea that linguistic structures affect the way we interpret a sentence is perhaps not surprising when we consider the variation of linguistic expressions in a language. The effect can become more interesting when the structures of different languages might affect the interpretation of an utterance. This idea is reminiscent of the Sapir-Whorf hypothesis, or the principle of linguistic relativity, that states that the structure of language affects our cognitive conceptualization of the world around us (Carroll, 1956). Recently, evidence has been reported supporting this idea. Fuhrman and Boroditsky (2010), for instance, found that speakers of Hebrew or English more often perceived temporal events in the direction that was congruent with the writing direction used by the participant. In another study, Boroditsky (2001) demonstrated that native language has also been shown to affect thought by demonstrating that speakers of Mandarin can view time in a vertical or horizontal dimension while speakers of English more easily interpret time along a horizontal dimension. These types of differences have also been found comparing word ordering effects in Spanish and German (Popović \& Ney, 2006), and contextual effects in German (Telljohann, Hinrichs \& Kübler, 2004). 


\subsection{Perception of an agent}

Similarly, there are studies that have examined the effect language can have on how an agent is perceived. Wolff, Jeon and Yu (2009) found that Korean does not allow for an object to be an agent (e.g., a key cannot open a door), while it is acceptable to say an object is the agent in Chinese and English (a key opened the door). This study illustrates that how a person perceives a causal agent can also be linked to how their language depicts causal agents. Wolff et al. (2009) found a difference in perception between Korean speakers and Chinese speakers, with Chinese speakers being more similar to English speakers in that the initiator of an action does not necessarily have to do so under its own power. Differences in causal attribution have also been found between Korean and American participants (Choi, Dalal, Kim-Prieto \& Park, 2003). While this was not a linguistic study per se, it is in accord with the Wolff et al. (2009) findings as the participants were native speakers of either Korean or English. In a study comparing Russian speakers and English speakers, Wolff and Ventura (2009) found that Russian speakers are more inclined to use internally generated forces for causal verbs, whereas English speakers consider both internally and externally generated forces. Fausey and Boroditsky (2011) found that Spanish and English speakers had similar eye-witness memory and agentive descriptions for events that were depicted as intentional. However, when the scenes viewed were depicted as accidental, English-speakers used agentive language more often than the Spanish-speakers.

\subsection{Agentive vs. non-agentive wording}

Judgments of responsibility have shown to be affected by agentive vs. nonagentive wording (Walster, 1966; Shaver, 1970; Fausey \& Boroditsky, 2010). Fausey and Boroditsky (2010) used two descriptions of the televised 'wardrobe malfunction' of the 2004 Superbowl half-time show during which Janet Jackson's breast was exposed during a dance with Justin Timberlake. The only difference between the two experimental conditions was that one used agentive language and the other did not. The agentive version stated ... 'he unfastened the snap and tore a part of the bodice. He slid the cover...' The non-agentive version stated ... 'a snap unfastened, and a part of the bodice tore. The cover slid... 'After reading the account of the event, participants who read the agentive version were not only more likely to assign blame to Mr. Timberlake; they also assigned 53\% more financial liability in the agentive condition compared to the non-agentive condition (i.e., Federal Communications Commission violation fees). Therefore, wording alone can affect how someone perceives a potentially accidental act.

Through a meta-analysis of more than 20 studies, Burger (1981) found that it is the perceiver's specific role in a potential accident that determines the attribution of blame. These findings are also in accord with Shaver (1970). According to 
Burger (1981), the differences found can be attributed to the similarity between the participant and the person in question (e.g., car owner) and the situation. This metaanalysis, at the very least, has shown that different situations and motivations can impact how a person assigns responsibility. It is possible that the construction of a particular language can impact the attribution of responsibility due to how it depicts a situation. Further research is necessary to establish whether native language can affect defensive attribution.

\subsection{The present study}

The current paper investigated whether different languages affect how people attribute responsibility. Much of our design follows Walster (1966), who tested the amount of responsibility assigned according to severity of the outcome and whether a person other than the agent was affected. Walster (1966) used four recorded scenarios of an event in which a car was involved in an accident. The scenarios all began with the same information, but ended with different information. In scenario 1, the outcome was that the car owner suffered no real damage. In scenario 2, the car hit a big tree at the bottom of a hill and was totaled. Scenario 3 stated that someone else could have been affected (people hurt and major property damage), but there were no severe consequences. In scenario 4 , there was significant property damage, a child was only slightly injured, but a man was severely injured. Walster (1966) found that if an outcome of an accidental event was more severe, the participants not only were more punitive in their assessment of the individual that owned the car, but also assigned more responsibility. The higher assignment of responsibility was also higher for when the event affected people other than the agent.

As with Walster (1966), the current study used a scenario describing an accident and made minor changes in each condition to examine whether there were differences found between those conditions. The participants read a brief scenario involving a family, a shopkeeper, and a vase that was broken. They then answered questions assessing the level of blame they assigned. Groups within each language group were further divided by the level of agentive wording used in the scenario. Spanish was chosen to compare with English, because of the difference of grammatical construction of accidental acts for the two languages. When an accident is described in Spanish, such as someone breaks a vase, the verb is conjugated in the third person and the literal translation would be something akin to 'The vase broke on him.' Whereas when the act was purposeful, the verb is conjugated to match the agent and the translation would be the same as either case in English, 'He broke the vase.' However, different from the study by Walster (1966) we manipulated the agentive wording rather than the severity of the outcome. Following the linguistic relativity principle, we hypothesized that the native language of a speaker would affect the attribution of blame, such that levels of responsibility would be assigned differently due to the participant's native language, specifically when using non-agentive wording. 
We predicted that the agentive conditions would elicit higher overall ratings for guilt for the main character in the story (and lower for the shop owner) by both Spanish- and English-speakers. However, we also predicted that the non-agentive conditions would elicit higher guilt ratings for the main character by the Spanishspeakers than the English-speakers due to the grammatical construction of using non-agentive language when referring to an accidental act in Spanish.

\section{Methods}

\subsection{Experiment}

A rating experiment was conducted with native speakers of English and Spanish judging the attribution of blame based on an agentive and a non-agentive sentence following a story they read. The purpose of the study was to investigate whether native language or agentive wording would have more of an impact on attribution of responsibility using Spanish- and English-speaking participants.

\subsection{Participants}

Eighty-five participants (about half female) were recruited from the Nashville area. Because of the desire to have a variety of language backgrounds of the speakers (i.e., native, bilingual, and those who did not speak the other language), traditional subject pools could not be used and churches were used as an ideal way of reaching two different language groups that were both similarly heterogeneous.

\subsection{Materials}

We followed Walster (1966) and Fausey and Boroditsky (2010) and used a single scenario for each language group. The materials were translated into Spanish by the first author, and independently verified by three native Spanish-speakers. An English version was also used for the English-speaking participants. Participants read a printed copy in their native language of a short vignette about a small claims court case in which a shop owner claims that a man owes him $\$ 1000$ for a broken vase. The four vignettes were identical except for the target sentence, which was changed according to the agentive condition (see Appendix A).

\subsection{Procedure}

Participants were asked to read a brief scenario (described above) and answer questions regarding different aspects of who was responsible and other factors that could impact their judgment. The questions that followed the vignettes were on a scale of 1 (Completely Disagree) to 7 (Completely Agree). Questions were also designed to have an attribution that was either internal (e.g., the main character in the scenario should have left his bags at the register) or external (The shop owner 
was responsible for the vase breaking) (see Appendix B). The questions were created such that all characters in the scenario could be held responsible for breaking the vase. The questions of each of the four conditions were counterbalanced in order of presentation to either start with a general internal attribution question (Martin was responsible for the vase breaking) or external attribution question (Another customer in the store said Martin was being careful, but the aisles were too close together for the situation).

Native Spanish $(n=45)$ or native English speakers $(n=40)$ were randomly assigned to one of four conditions of literal wording in each respective language: 1$)$ agentive: the main character in the scenario broke the vase; 2) somewhat agentive: the vase was broken by the main character in the scenario; 3) somewhat non-agentive: the vase was broken; 4) non-agentive: the vase broke. The experiments thus used a 2 (language) x 4 (agentive) mixed factorial design. There were approximately 10 participants per group. The two independent variables, language and agentive wording, were treated as between-subjects factors.

\section{Results}

\subsection{Multidimensional scaling}

The ratings of the 17 questions provide an overview of attribution of blame. In the analysis we aimed to distinguish between internal (personal) and external (situational) attributions of blame (Sosis, 1974; Wallace \& Hinsz, 2009). For example, a question that asked if the main character broke the vase would be considered an internal attribution for the main character, while the question that asked if the aisles were too close together would be an external attribution. In order to determine how participants viewed internal and external attributions of the current scenario, we conducted a multidimensional scaling (MDS) using the ALSCAL algorithm (Kruskal \& Wish, 1978) for the ratings of the English speakers and the Spanish speakers. The Euclidian distance between the ratings of the questions was then calculated per language group with a maximum of 30 iterations, and a stress convergence $=.001$. The fitting of the data for the English and Spanish speakers was good (Stress $=.32$, $\mathrm{R}^{2}=.63$ and Stress $=.25, \mathrm{R}^{2}=.74$, respectively). Figure $1 \mathrm{a}$ and $1 \mathrm{~b}$ show the clustering of the questions for the English (1a) and the Spanish speakers (1b). As both figures show, the mapping of the questions between the two language groups is very similar with a bidimensional regression yielding a significant correlation, $r=.53, p<.03, n$ $=17$. 


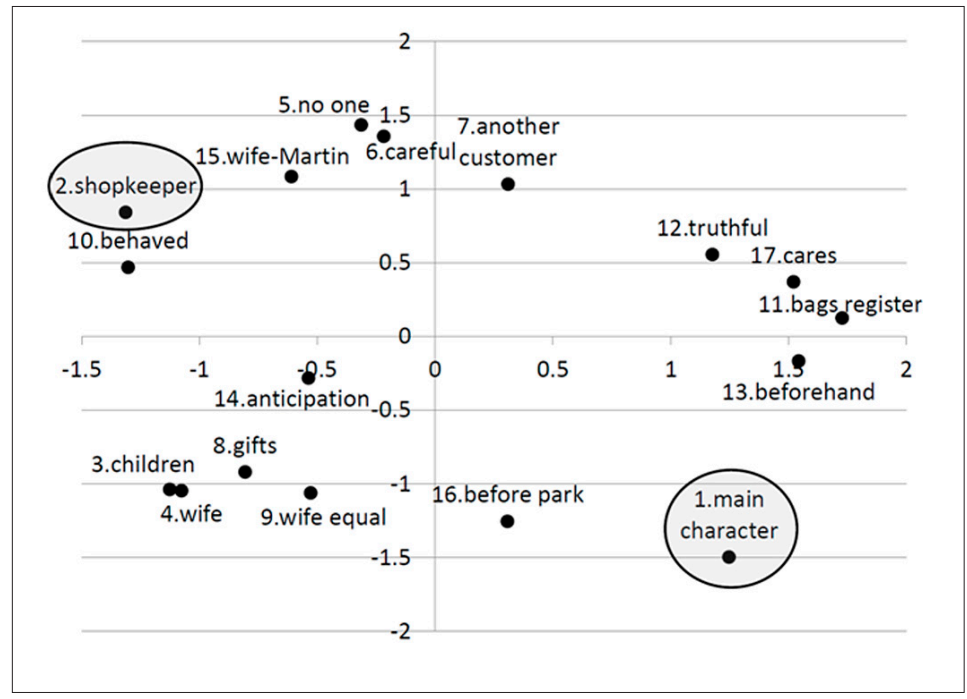

Figure 1a. Multidimensional scaling of the answers of the 17 questions by Englishspeaking participants.

Note: X-axis represents internal vs. external attribution of blame, y-axis the level of blame.

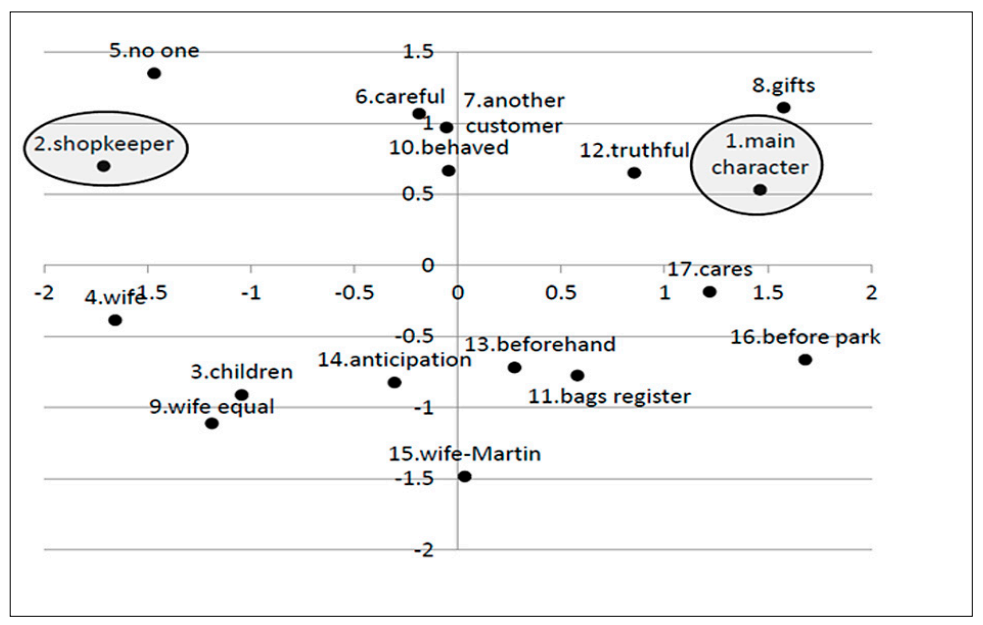

Figure 1b. Multidimensional scaling of the answers of the 17 questions by Spanishspeaking participants.

Note: $\mathrm{X}$-axis represents internal vs. external attribution of blame, $\mathrm{y}$-axis the level of blame. 
We selected the two characters that best represented the internal and external attribution dimension (x-axis in the graph): the main character and the shopkeeper. In order to assess if there are differences of blame between English and Spanishspeaking participants, as well as the four types of agentive wording, a two-way analysis of variance (ANOVA) was conducted to assess level of responsibility for the main character in the scenario presented where a vase was broken. With respect to how much participants held the main character in the scenario responsible, language (Spanish $M=4.56, S D=2.41$, or English $M=4.74, S D=1.39$ ) did not significantly affect blame, $F(1,112)=1.92, M S E=3.72, p=.17$. Agentive wording across the four conditions $(M=4.64, S D=1.99)$ also did not significantly affect the extent to which the main character in the scenario was blamed, $F(3,112)=0.72, M S E=3.72, p=$ .54. Finally, there was no interaction between language and agentive wording, $F(1$, $112)=0.32, M S E=3.72, p=.81$. This suggests that neither language nor agentive wording had an effect on responsibility, when looking at only the central figure in the presented scenario. Perhaps this finding is not surprising as it seems reasonable that the central figure in the story, when referenced by name, would intuitively be assigned more responsibility, regardless of the language (Fausey \& Boroditsky, 2010).

\subsection{Relative attribution of blame}

More of interest to the relativity hypothesis is not the absolute attribution of blame (e.g., is the main character guilty), but the relative attribution of blame (e.g., is the main character more or less responsible than other characters). To address this question, we compared the attribution of blame to main character with the attribution of blame to his opponent (the shop owner). Accidents are usually depicted in Spanish by using the non-agentive construction (e.g., lit. The vase broke on him). This construction is often called 'no fault se' (Lafford \& Salaberry, 2003; Herschberger, Navey-Davis \& Borrás, 2011). Therefore, there may be a difference between the two language groups when using agentive versus non-agentive wording. We conducted a two-way ANOVA comparing responsibility ratings for the main character in the scenario with those for the owner of the shop in the agentive and non-agentive conditions in English and Spanish. In both of these conditions, the responsibility ratings for the main character were significantly higher than the owner of the shop in the agentive condition in both Spanish and English and lower for the owner of the shop, $F(1,24)=16.13, p<.001$ (Figure 2a). 


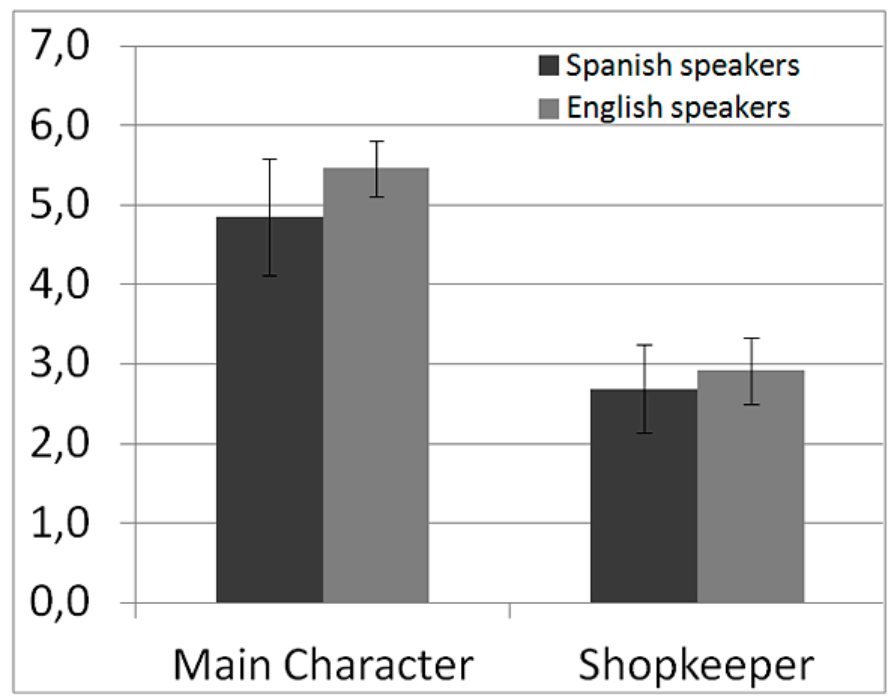

Figure 2a. Level of responsibility (y-axis) for main character and shop owner (agentive wording).

However, when using non-agentive wording, there was a reversal for Spanish and English-speakers indicating the responsibility assigned for the main character rose for Spanish-speakers in the non-agentive condition, $F(1,18)$ $=21.32, p<.001$ (Figure 2b).

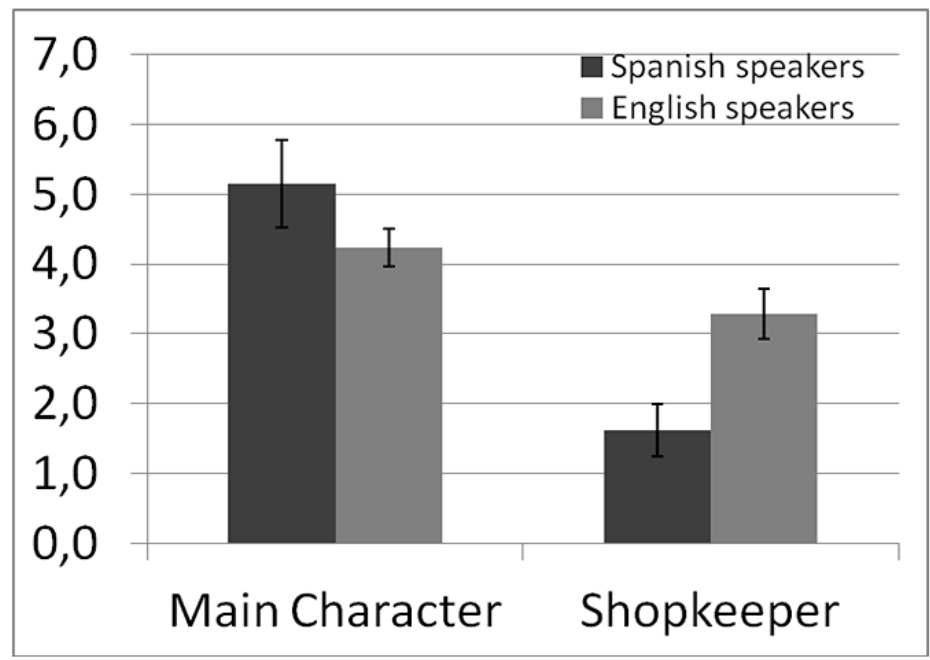

Figure 2b. Level of responsibility (y-axis) for main character and shop owner (non-agentive wording). 
This suggests that the Spanish speaking participants rated responsibility for the main character higher than the English speakers because of an assumption that can arise from using the convention of non-agentive language when depicting an accident (Lafford \& Salaberry, 2003; Herschberger et al., 2011). In Spanish, the culpability is implied in the non-agentive construction, because one would not think that vases are capable of breaking themselves and the person who broke it is a mere bystander. In short, how accidents are depicted in Spanish affect how speakers of that language interpret blame.

\section{Discussion}

\subsection{Goals and findings}

The present study aimed at determining whether a person's native language influenced how they assigned responsibility. Participants read a scenario in which an accident occurred for which responsibility could be attributed to different individuals. In two conditions of the experiment the scenario was the same, but one version was in English, the other in Spanish. In addition, four versions of the Spanish text and the English text were created; in which participants saw either an agentive version, or a non-agentive version. Findings demonstrated that there was no difference between the responsibility ratings for two individuals who could be blamed for the accident. However, the participants in the non-agentive condition showed a significant difference between Spanish and English-speakers. Further analysis using multidimensional scaling also demonstrated a language difference for how participants grouped external and internal attributions. The current findings are in line with previous research that demonstrates a link between native language and perception of an event, especially one of a causal or agentive nature (e.g., Boroditsky, 2001; Wolff et al., 2009; Fausey \& Boroditsky, 2010). Fausey and Boroditsky (2010) demonstrated how agentive wording can affect not only who is responsible for an event, but also how much punitive damage should be assigned. This is an important finding in and of itself, but the exploration of how speakers of different languages are affected by agentive language is also important.

The main findings regarding the effect of language supported our hypotheses of language being the factor that will impact attribution of responsibility, but the results of analyses for the internal and external attributions were only marginally significant for agentive wording. There are a number of explanations for the lack of effect of language in this instance. First, the linguistic relativity principle predicts a subtle effect of language. Various studies have dismissed a strong version of the Sapir-Whorf hypothesis, but have defended a weaker version (Gentner \& Goldin-Meadow, 2003), confirming subtle effects of language on thought. Secondly, off-line responses were recorded. That is, results might have been stronger with more fine-grained measures that would prevent the participant from making deliberate decisions after carefully 
weighing the options. Finally, and perhaps most importantly, the findings reported so far are based on the internal and external attributions that were predetermined. It is possible that, with the addition of more scenarios and questions that can detect subtle effect sizes, this type of research could begin to reveal the nature of assignment of responsibility for speakers of different languages and agentive wording.

\subsection{Limitations}

There were some possible limitations to the present study. One issue could be the use of a single scenario rather than multiple scenarios. This design was used in both Walster (1966) and Fausey and Boroditsky (2010). The current study was not designed to assess judgment of responsibility across all possible situations. The goal was to explore whether a difference was present for different wording presentation when looking at responses from speakers of Spanish and English, which was found. There could have also been more subjects used for the study. However, even with the presence of this limitation, significant results were nonetheless obtained.

Some readers may wonder whether bilingualism inadvertenly affected the results. While there were some Spanish-English bilingual participants, we do not consider this a confounding factor. First, there were a low number of people who self-reported as being high functioning in both languages. There were only eight Spanish-speakers that reported a high level of functioning in English, and only two English-speakers that reported a high level of functioning in Spanish. Moreover, Cunningham, Vaid and Chen (2011) compared Spanish-English bilinguals and their assessment of agentive assignment. Cunningham et al. (2011) found that when English was the presentation language, English bilinguals perceived the agentive nature of a text just as the English monolinguals perceived the text. Spanish bilinguals, on the other hand, were more apt to choose non-agentive responses when presented with English text as opposed to their monolingual English counterparts. However, the participants in the present study saw text in the native language that they chose in the beginning of the study. Therefore, we do not anticipate a confound from the bilingual participants.

\section{CONCLUSIONS}

Two interesting findings emerged from the data. First, there were differences in attribution of responsibility between language groups, when the participants saw the non-agentive wording. This indicates that Spanish and English speakers react differently depending on wording used. Second, internal and external factors were used in the deliberation of who was ultimately responsible for the vase breaking; this was also dependent on the language group. The difference between internal and external factors begins to demonstrate that speakers of different languages can view responsibility in different ways. 


\section{REFERENCES}

Boroditsky, L. (2001). Does language shape thought? English and Mandarin speakers' conceptions of time. Cognitive Psychology, 43, 1-22.

Burger, J. M. (1981). Motivational biases in the attribution of responsibility for an accident: A meta-analysis of the defensive-attribution hypothesis. Psychological Bulletin, 90, 496-512.

Carroll, J. B. (1956). Language, thought and reality: Selected writings of Benjamin Lee Whorf. Cambridge, MA: MIT Press.

Choi, I., Dalal, R., Kim-Prieto, C. \& Park, H. (2003). Culture and judgment of causal relevance. Journal of Personality and Social Psychology, 84, 46-59.

Cunningham, D., Vaid, J. \& Chen, H. (2011). Yo no tiré, se cayó solito, 'I did not throw it, it just fell down': Interpreting and recounting accidental events in Spanish and English. In V. Cook \& B. Bassetti (Eds.), Language and Bilingual Cognition (pp. 407-430). Philadelphia, PA: Psychology Press.

Fausey, C. \& Boroditsky, L. (2010). Subtle linguistic cues influence perceived blame and financial liability. Psychonomic Bulletin \& Review, 17, 644-650.

Fausey, C. \& Boroditsky, L. (2011). Who dunnit? Cross-linguistic differences in eyewitness memory. Psychonomic Bulletin and Review, 18, 150-157.

Fuhrman, O. \& Boroditsky, L. (2010). Cross-cultural differences in mental representations of time: Evidence from an implicit non-linguistic task. Cognitive Science, 34, 1430-1451.

Gentner, D. \& Goldin-Meadow, S. (Eds.) (2003). Language in mind: Advances in the study of language and thought. Cambridge, MA: MIT Press.

Herschberger, R., Navey-Davis, S. \& Borrás, A. G. (2011). Viajes: Introducción el Español. Boston, MA: Heinle.

Kruskal, J. \& Wish, M. (1978). Multidimensional scaling. Beverly Hills, CA: Sage Publications.

Lafford, B. \& Salaberry, R. (Eds.) (2003). Spanish second language acquisition: The state of the science. Washington, DC: Georgetown Press.

Peters, G. (2010.). American Presidency Project [on-line]. Retrieved from: http://www. presidency.ucsb.edu

Popović, M. \& Ney, H. (2006). POS-based word reorderings for statistical machine translation. Proceedings of the $5^{\text {th }}$ International Conference on Language Resources and Evaluation, Genoa, Italy. 
Shaver, K. G. (1970). Defensive attribution: Effects of severity and relevance on the responsibility assigned for an accident. Journal of Personality and Social Psycbology, $14,101-113$.

Sosis, R. (1974). Internal-external control and the perception of responsibility of another for an accident. Journal of Personality and Social Psychology, 30, 393-399.

Telljohann, H., Hinrichs, E. W. \& Kübler, S. (2004). The TüBa-D/Z Treebank Annotating German with a context-free backbone. Proceedings of the Fourth International Conference on Language Resources and Evaluation (LREC), Lisbon, Portugal.

Wallace, D. \& Hinsz, V. (2009). Group members as actors and observers in attributions of responsibility for group performance. Small Group Research, 40, 52-71.

Walster, E. (1966). Assignment of responsibility for an accident. Journal of Personality and Social Psychology, 3, 73-79.

Wolff, P., Jeon, G. \& Yu, L. (2009). Causers in English, Korean, and Chinese and the individuation of events. Language and Cognition, 1(2), 165-194.

Wolff, P. \& Ventura, T. (2009). When Russians learn English: How the semantics of causation may change. Bilingualism: Language and Cognition, 12, 153-176. 


\section{APPENDIX A}

\section{English}

In a small claims court, a shop owner claims that Martin T. broke a vase and owes him \$1000. Martin took his wife and two children ages 6 and 9, to a large resort town for vacation. After a long day at an amusement park, they went shopping and he bought many things for his family and friends back home. Martin was carrying many large bags full of all the things he purchased. In one gift shop, his children were exhausted from the full day and were being restless. While carrying all his purchases and trying to calm his children, [Martin broke a vase; A vase was broken by Martin; A vase was broken; A vase broke]. The price of the vase was $\$ 1000$.

\section{Español}

En una corte de reclamos menores, un dueño de tienda reclama que Martín T. rompió un florero y le debe $\$ 1000$. Martín llevó a su esposa y a sus dos hijos de 6 y 9 años de vacaciones a un gran complejo turístico. Después de un largo día en un parque de diversiones, se fueron de compras y él compró muchas cosas para su familia y amigos. Martín cargaba muchas bolsas grandes llenas de las cosas que había comprado. En una tienda de regalos, sus hijos estaban exhaustos y estaban inquietos. Mientras cargaba todas sus compras, y trataba de calmar a sus hijos, [Martín quebró un florero; un florero fue quebrado por Martín; un florero fue quebrado; se le quebró un florero]. El valor del florero fue de $\$ 1000{ }^{1}$

1 Some of the wording in the Spanish version may seem unusual (e.g., using quebrar rather than romper). Unfortunately, we cannot change the Spanish text in this portion because this text is what participants read. The native Spanish speakers that consulted on this study, as well as the participants upon completion of the study, agreed that the wording used conveyed the point sufficiently.

\section{APPENDIX B}

[Provided in native language of participant]

For the following questions, please circle the number that best states your response.

[Provided after each question]

$\begin{array}{ccccccc}1 & 2 & 3 & 4 & 5 & 6 & 7 \\ \text { Completely } & \text { Strongly } & \text { Tend to } & \text { Neutral } & \text { Tend to } & \text { Strongly } & \text { Completely } \\ \text { Disagree } & \text { Disagree } & \text { Disagree } & & \text { Agree } & \text { Agree } & \text { Agree }\end{array}$


1. Martin was responsible for the vase breaking.

2. The shop owner was responsible for the vase breaking.

3. The children were responsible for the vase breaking.

4. The wife was responsible for the vase breaking.

5. No one was responsible for the vase breaking.

6. Martin was usually very careful in stores. He was careful on the day the vase was broken.*

7. Another customer in the store said Martin was being careful, but the aisles were too close together for the situation. Martin was being careful in the aisles.*

8. Martin was buying gifts for people other than himself, but this does not affect how responsible he was for the vase.

9. Martin's wife was equally responsible as Martin. $\dagger$

10. Martin's children were usually well behaved.

11. Martin should have left his bags at the register.*

12. The shop owner was truthful when he said the vase was worth $\$ 1000$.

13. Martin could have done something with his children before entering the shop to make his children less restless.*

14. The owner of the store should have anticipated tired and restless children and designed the shop accordingly. $\dagger$

15. Martin's wife was not as responsible as Martin. $\dagger$

16. If Martin and his family went to the gift shop before the trip to the amusement park, Martin would have the same level of responsibility for the vase breaking.

17. Martin cares for his family deeply.

Note: * denotes questions originally determined to be used for the internally attributed combined score; $\nmid$ denotes questions originally determined to be used for the externally attributed combined score. 